\title{
Die bediening van die wil van God aan gelowiges in nood
}

\author{
A.G.S. Venter \\ Gereformeerde Kerk Randburg-Oos \\ RANDBURG
}

Abstract

The ministering of the will of God to believers in distress

In this article exegetical, pastoral and practical perspectwes are grven on the church's mumistr. to people in distress. The goal of the church's mumstry is not to explain the will of (jod ratonally: the church should assist ihe heliever in distress to enter mos a persomal relautonship with God. The postor should have a true relatronship with (iod and a sincere relatoms/up should exist hemeen pastor and church member. With these relatomshups as a hasis, the helever can he led to accept the will of God in his her life as a loving, caring will In practice. the mumsiry of the church should comprise five aspects: chrstological conmmumcaton, father-centred imegranon, pneumatological assistance, eschatological viston and personal grow'th.

\section{Inleiding}

Wanneer die gelowige in nood verkeer, ell dié nood juis impliseer dat daar in ingrype in die lewensbestaan kom, kom hy ook te staan voor trae soos die volgende: Hoe moet ek God se wil rym met dit wat nou met my gebeur? Waarom laat God dit toe? Word ek gestraf vir iets wat ek verkeerd gedoen het? Wat is die doel van God met my lewe?

In hierdie artikel word gepoog on vanuit die Bybel sekere eksegetiese perspektiewe te open wat as vertrekpunte kan dien vir die kerklike bediening van die mens in nood. Sekcre pastorale en dogmatiese aspekte word aangeraak, maar dit is me die fokuspunt in hierdie ondersoek nie

Eerstens word enkele Skrifturlike gegewens oor die wil van God behandel. Daama word gekyk na fette uit die Skrif en uit die werklikheid oor die nood van 
die mens. Laastens word dié riglyne deurgetrek na die praktiese bediening aan gelowiges.

\section{Die wil van God}

\subsection{Ou-Testamentiese riglyne}

Dit is duidelik uit die Ou Testament dat die wil van God vasstaan, en dat die volk dit in geloof as 'n heilsame wil aanvaar het (vgl. verder 3.1).

In Job 38:2 en 42:3 gebruik eers God en daarna Job dieselfde woorde: "Wie maak die raadsbesluit daar tot duistenis met woorde sonder kemnis." In God se mond is dit 'n beskuldiging dat Job nie God se wil begryp het nie en tog daaroor kritiek het; in Job se mond is dit 'n belydenis van skuld en gebrek aan insig (vgl. Kroeze, 1961:466). Hieruit blyk dat die wil van God vasstaan en bo die mens se begrip uitgaan. Die mens kan alleen in magtelose onbegrip voor God se wil buig. Tog is die oomblik van nood by Job die oomblik van warlıeid en insig, want toe het hy God gesien. Hy het naby aan God gekom deur al sy worstelinge heen.

Verdere gegewens uit die Ou Testament dui ook daarop dat die gelowige nie die wil van God as iets abstrak en ver beleef het nie (vgl onder andere Psalm 33:11, 12; 73:23-28, Miga 4:12, 13).

\section{$2.2 \Theta \varepsilon \hat{\varepsilon} \lambda \eta \mu \alpha$ in die Nuwe Testament}

Die Griekse woord $\theta \varepsilon \hat{\imath} \eta \mu \alpha$ word hoofsaaklik in twee betekenisse in die Nuwe Testament ten opsigte van die wil van God gebruik, naamlik as die doel (in die betekenis van raadsbesluit, plan, bedoeling van God) en as begeerte (in die betekenis van God se voorskrif, wet - vgl. Matt 7:21). Vir die doeleindes van hierdie artikel word op die eerste betekenis ingegaan omdat hierdie begrip die bedoeling van God in die praktiese situasie van die mens raak.

\subsubsection{God laat sy wil geskied}

In Matteus 6:10 (Onse Vader-gebed) het die bede dat God se wil geskied 'n inhoudryke betekenis. Hierdie betekenis word in die Heidelbergse Kategismus Sondag 49 so verklaar: die mens bid om sy eie wil prys te gee, hom aan God se wil te onderwerp en ook God se wil in sy daaglikse lewe unt te voer. Die gelowige bid vir die rumte wat God se wil vir hom skep om onder die wil van God te kan leef.

Toe die gelowiges nie vir Paulus kon oorreed on nie na Jerusalem te gaan nie omdat hy daar gevange geneem sou word, het die gelowiges stil geraak en gesê: "Laat die wil van die Here geskied" (Hand 21:14). Die ingressiewe aoristus 


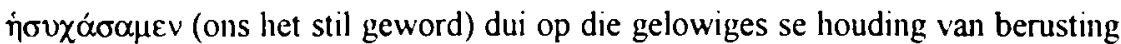
en aanvaarding van die wil van God. Volgens Jakobus 4:15 moet die gelowige in sy lewe sê: "As die Here wil ..." - 'n gesindheid wat ook getuig van 'n aanvaarding van en oorgawe aan die wil van God (vgl. ook Matt. 26:42).

Hierdie gedeeltes getuig van gelowiges wat kinderlik die wil van God (moet) aanvaar.

\subsubsection{God se wil tot redding van die sondaar}

'n Verdere gebruik van die woord $\theta \dot{\varepsilon} \lambda \eta \mu \alpha$ is waar dit verband hou met die wil van God in Jesus Cluristus, spesifiek met die oog op die redding van die sondaar, die gelowige in Jesus Christus.

Dit is nie die wil van die Vader dat een van die kleintjies verlore sal gaan nie, sê Jesus (Matt. 18:14). In die Johanmes-evangelie maak Jesus melding daarvan dat Hy gekom het volgens die wil van sy Vader $(4: 34,5: 30)$ en dan spesifiek dat $\mathrm{Hy}$ dit gedoen het tot redding van die kinders van God $(6: 38,39,40)$. By hierdie saak sluit die res van die Nuwe Testannent aan wanneer die wil van God aan die verlossingswerk van Jesus Christus verbind word (Gal. 1:4, Ef 1:5, 9, 11, Heb. 10:9, 10;1 Joh. 2:17).

In Efesiërs 1:9-11 word spesifiek melding gemaak van die gelseimenis van God se wil wat Hy bekend gemaak het en in Christus tot uitvoering gebring het. Alles is bewerk en bercik deur die werk van Jesus Christus en alles word bepaal deur "die raad van die wil" vall God ( van God gestel as die bepalende beginsel in die redding van die sondaar (vgl. Kittel, TDNT, 1969:635).

Uit hierdie gegewens blyk dit dat die wil van God, in die betekenis van 'die doel wat God voor oë het', direk verband hou met die koms en die werk van Jesus Christus en as sodanig benader moet word. Die wil van God is 'n genadige wil. God wil die verlossing van sondaars. Met hierdie uitgangspunt kom die gelowige te staan voor die liefdevolle God in Jesus Christus wanneer hy oor die wil van God nadink

\subsection{Boú ${ }_{0} \mu \alpha$ en $\beta o v ́ \lambda \eta \mu \alpha$ in die Nuwe Testament}

Volgens Lukas 22:42 sê Jesus: "Vader, as $\mathrm{U}$ tog maar hierdie beker van My wil (ßoú $\lambda \mathbf{c}$ ) wegneem Laat nogtans nie my wil $(\theta \dot{\varepsilon} \lambda \eta \mu \alpha)$ nie, maar u s'n geskied". Jesus se gebruik van $\beta$ in $\lambda$ op $\alpha$ stem ooreen met die inhoud van hierdie woord soos gebruik ten opsigte van Josef in Matteus 1.19, waarolgens Josef hom

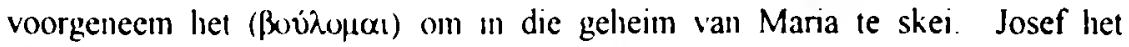

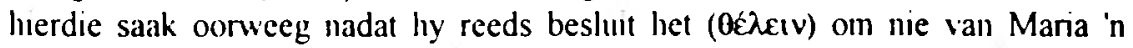
openbare voorbeeld te maak nie. Die woord Buviloua het dus 'n implisiete 
betekenis van die oorweging in die proses van besluitneming. $\theta \varepsilon \hat{\lambda} \varepsilon \iota v$ dui in 'n sterker mate op 'n vaste besluit of keuse (vgl. Greijdanus, 1941:1081; Plummer, 1942:508).

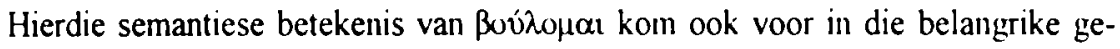
deelte in Romeine 9:16-19:

So hang dit dan nie af van die een wat wil ( $\theta \dot{e} \lambda \varepsilon \iota v$ ) of van die een wat loop nie, maar van God wat barmhartig is ... So is Hy dan barmhartig oor wie Hy wil ( $\theta \varepsilon \lambda \varepsilon ı v)$ en verhard Hy wie Hy wil ( $\theta \dot{\varepsilon} \lambda \varepsilon \imath v)$. Jy sal dan vir my sê: Waarom verwyt Hy dan nog, want wie het sy wil (ßovi $\lambda \eta \mu \alpha)$ weerstaan?

In hierdie gedeelte moet $\beta$ vó $\eta \mu \alpha$ nie verstaan word as God se raad of voomeme nie, maar as die werking van sy wil (Ridderbos, 1959:218). Buv́ $\eta \mu \alpha$ handel in hierdie gedeelte oor die besluitnemingsproses van God Die mens staan in hierdie opsig nie voor 'n koue en afsydige wil van God nie, maar beroep hom op die lewende God wat betrokke is in die redding en die lewe van sy kinders.

Op grond van bogenoemde uitgangspunt is die direkte verband van dit wat volg op Romeine 9:19 veelseggend omdat dit verwys na die pottebakker en die klei: die klei kan nie vir die pottebakker voorskryf hoe die pottebakker moet werk nie Die antwoord van die gelowige op sy vrae oor die wil van God is nie 'n teologiesapologetiese antwoord nie, maar 'n religieuse antwoord (Ridderbos, 1959:218).

Bostaande gegewens dui daarop dat die gelowige sy verhouding as kind tot sy hemelse Vader as die basis moet neem wanneer hy worstel met die probleem van die wil van God in sy aardse nood. Die gelowige staan nie teenoor 'n koue, veraf God nie, maar hy tree in gesprek met sy hemelse Vader. Hierdie gegewens getuig van 'n band van innigheid tussen die Vader en sy kinders wat 'n belangrike basis is vir die gelowige wanneer hy die wil van God in sy lewe aanvaar.

\subsection{Gevolgtrekking}

* Die wil van God moet gesien word as primêr 'n genadige wil wat sentreer in God se genade vir die gelowige

* Die gelowige moet die wil van God kinderlik sien vanuit die Vader-kindverhouding

* Die wil van God gee vastigheid in die lewe van die gelowige.

\section{Die nood van gelowiges}

\subsection{Ou-Testamentiese riglyne}

Die nood van die mens het begin met die sondeval in Genesis 3. Die straf op die sonde het as inhoud gehad dat die mens sou swoeg en sweet, dat hy sou worstel 
met dorings en distels en dat hy voor die dood te staan gekom het (Gen. 3:17-19). Ook sou die vrou met smart kinders baar, sou die vrou na die man hunker en sou hy oor haar heers (Gen. 3:16). Daarmee is die oorsprong en omvang van die mens se nood aangedui.

God het die mens uit die Paradys gestuur (Gen. 3:23, 24); daarom het die mens in 'n versteurde verhouding met God te staan gekom. God het egter die belofte gegee dat die kop van die slang vermorsel sou word (Gen. 3:15). Op grond van God se belofte dat Jesus Christus die Satan sal oorwin, blyk dit dat God die mens nie in sy nood alleen gelaat het nie

Abraham en Sarai het die nood van kinderloosheid ondervind (Gen. 15:3) en hulle moes net in God se beloftes bly glo. Uiteindelik, na jare se wag, voorsien God deur die geboorte van Isak. Abraham se geloof word beproef, ook toe hy Isak moet gaan offer op Moria. Maar weer eens voorsien God die ram, sodal Abraham die plek noem 'Die Here voorsien' (Gen. 22:14) Weer eens blyk dit dat God voorsien in die nood van sy kinders.

In Psalm 73 worstel Asaf met die feit dat die ongelowige dikwels voorspoedig is terwyl die gelowige ly. Geen verstandelıke antwoord is egter die antwoord nie; die oorheersende besef is dat 'Wat my aangaan, dit is vir my goed om naby God te wees' (v. 28). In hierdie besef van aanvaarding lê die antwoord vir die gelowige wat voor die onbegryplike weë van God se regering te staan kom. Die gelowige kan sê: "Al loop alles skynbaar verkeerd, nogtans sal ek in die Here jubel, sal ek juig in God, my Redder" (Hab. 3:18). Die gelowige moet "die straf wat van die Here kom" aanvaar, "want die Here straf die mens wat Hy liefhet net soos 'n vader doen met sy seun" (Spr. 3:11, 12).

Die geskiedenis van Job is 'n baie bekende voorbeeld van die teenspoed en gepaardgaande nood van die gelowige. Job enaar die nood van bitterheid, selfbejaınmering, vyandskap, wanhoop, opstand en verwyt (De Klerk, 1968:68).

Dit is opmerklik dat Job voondurend vanuit sy verhouding met God worstel en altyd antwoorde fonmuleer met sy geloof in God op die voorgrond (Job 1:21, 2 : $10,13: 15 ; 16: 18-21 ; 19: 25)$. Ook hy word mie in sy nood alleen gelaat nie. God bly in gesprek met hom en hy bly in gesprek met God.

Maar dit is duidelik dat die rasionalisering van die probleem geen antwoord bring me (Swanepoel, 1992:51, 52). Die vriende van Job rasionaliseer deur 'n verband te sien tussen 'n mens se dade en sy lyde en Job rasionaliseer deur te beredeneer dat hy nie die teenspoed verdien het nie.

God verstaan die moedeloosheid (en selfs die opstandigheid) van die mens wat in nood verkeer en verwerp hom me daaroor nie. Dit is die wyse waarop Hy mense tot geloof of verdieping van hulle geloof in Hom bring (Wessels, 1991:3). 


\subsection{Nuwe-Testamentiese riglyne}

\subsubsection{Die lyde van Jesus Christus}

Jesus se lyding was nie die gevolg van die noodlot of die heroïese daad van 'n martelaarsfiguur nie (Louw, 1982:23). God het vantevore verkondig dat die Christus moet ly, en hierdie verkondiging is in die lyde van Christus vervul (Hand. 3:18; vgl. ook Luk. 24:25-27; Mark. 14:21).

In die Goddelike beskikking van die lyde van Christus openbaar God hoe Hy in sy ontferming imnige bemoeienis met sy kinders maak. God kom staan in die lyde van Christus by die gelowige in sy nood. So word die belofte in Jesaja 43:2 vervul (“... as jy deur die water gaan, is Ek by jou ...").

Die lyding van Christus gaan nie primèr om die mens nie, unaar veral om die vervulling van God se heilsplan om die sonde en die dood te oorwin. God herstel die verhouding tussen Hom en die mens en neem die sonde van die mens weg. Dit wat die gelowige van God sou verwyder, naamlik die sonde, is deur die lyde van Christus verwyder

\subsubsection{Die nood van gelowiges}

'n Aangrypende voorbeeld van die nood van 'n gelowige is die van Johannes die Doper in die gevangenis. Naas sy nood dat hy in die gevangenis was, het hy voor die probleem gestaan of Jesus waarlik die Messias was (Matt. 11:3; Luk. 7:19). Jesus dra aan die dissipels van Johannes op on aan Johamnes te gaan vertel wat hulle sien en hoor. Hulle word die eerste oog- en oorgetuies van Jesus se evangelie. Die feite van die werk van Jesus is die basis vir die troos. Jesus trek as 't ware Johannes nader aan sy dade en woorde, on vanuit hierdic posisie sy nood draaglik te maak.

Petrus was in die grootste geestelike nood nadat hy Jesus verloën het en het bitterlik daaroor gehuil (Matt. 26:75). Petrus word herstel deur die vraag of hy Jesus waarlik liefhet (Joh. 21:15-17). Jesus trek Petrus nader om vanuit die posisie van sy liefde vir Christus sy lewe te herstel en sy bediening voort te sit.

In Handelinge word die noodsituasies waarin die gelowiges hulle bevind het, telkens geteken vanuit die perspektief dat die gelowiges nie wanhoop nie, maar kragtige geloof en volharding openbaar (vgl Hand 4:24 e.v.). Dit is opmerklik hoe Paulus en Silas lofliedere sing in die gevangenis (Hand. 16:25). Die gelowiges het nie aan die nabyheid en sorg van God getwyfel nie.

Die nood van die gelowiges word in die Nuwe Testannent telkens in 'n positiewe lig gestel. Die 'doring in die vlees' van Paulus lei hom tot die besef dat die genade van God vir hom genoeg is sodat hy in sy swakhede roem en bly is oor 
swaklıede, beledigings, ontberings, vervolginge en moeilikhede (2 Kor. 12:7-10). In Jakobus I word die gelowiges opgeroep om bly te wees wanneer allerlei beproewings oor hulle kom omdat hulle deur die toets van hulle geloof tot volharding kom (Jak. 1:2). Die gelowige moet vanuit die posisie van die nabyheid van God tot die slotsom van die geloof kom. Hierby sluit die boodskap van Hebreërs 12 aan, waar die gelowige opgeroep word om die tugtiginge te hanteer vanut die verhouding van 'n kind tot sy Hemelse Vader.

\subsection{Gevolgtrekking}

Uit bogenoemde Skriftuurlike gegewens blyk die volgende:

* Dit is nie vreemd dat gelowiges hulle in nood kan bevind nie.

* God laat die gelowige nie alleen in sy nood nie

* Die gelowige kan sy nood alleen venverk vanuit die perspektief dat hy naby aan God is. Hy word deur God nader getrek, deur en in sy nood

* Die gelowige hanteer sy noodsituasie deur geloof en gebed

* Daar word nie oor 'n verduideliking van die wil van God gehandel wanneer die gelowige in die nood is nie. Hy word wel gelei tot 'n gelowige aanvaarding van die wil van God en 'n positiewe besef van sy nabylieid by God deur Jesus Christus.

\section{Die bedienaar en die bediening}

\subsection{Die bedienaar}

Die pastor staan nie langs God nie, maar langs die lidmaat in sy' nood. Saam met die lidmaat moet gevra word na die wil van God en saam met die lidmaat moet die antwoorde uit die Woord van God verkry word. Die herderlike bediening is self ' $n$ daad van versoening (Venter, 1976:53). In die werk van die pastor moet die lidmaat die versoenende woord van Jesus Christus hoor ell ook die versoening in Christus beleef. Die pastor moet in sy pastorale optrede en gestalte die nabyheid van God simboliseer (Muller, 1981:26).

Die bedienaar sal dus die wil van God in sy eie lewe, in besonder in sy eie noodsituasies, moet toepas. Die bedienaar se eie nood kan bestaan uit persoonlike geloofsirac, eie bedieningsnood, eie huislike en huweliksomstandighede. Die bedienaar moet eerlik voor God en naby aan God leef en biddende die wil van God in sy cie lewe opsoek.

In hierdie verband moet die woord empante gekwalifiseer word Die pastor moet nie net empatie hê in die vonn van begrip en meelewing nie. Hy moet aan die gelowige in nood "die patos van die lewende Verbondsgod wat in genadige be- 
roering is oor die lyding van die mens" (Louw, 1982:16) duidelik laat word. God self is innerlik ontroer deur die nood van sy kinders (Jer. 31:20) soos die vader van die verlore seun in Lukas 15:20. Bimne die warnte van hierdie bewoënheid van God oor sy kinders, beleef die gelowige in nood die innigheid van God se vertroostende nabylieid (vgl. Fil. 2:1).

Empatie in die pastorale verhouding beteken dat daar werklike geloofseenheid tussen bedienaar en lidmaat is. Vanuit sy eie verhouding met God moet daar 'n geloofsverhouding tussen pastor en lidmaat wees. Eers dan kan die bedienaar die belangrike eis nakom deur begrypend, ondersteunend en luisterend saam met die lidmaat, met die Woord van God in die hand, onder die wil van God te buig.

\subsection{Lyding, vergelding en opvoeding}

Is daar enige verband tussen 'n mens se dade en die teenspoed wat hy crvaar?

In die Ou Testament is daar wel 'n verbinding tussen lyding en vergelding, hetsy kollektief of individueel. Job ell Asaf (Ps. 73) worstel daarmee, so ook Dawid (Ps. 10), Habakuk (1:13) en die Prediker (7:15). In die Ou Testament word die doel van lyding as vergelding ten opsigte van die volk van God gedra deur die begrippe tugtiging tot behoud, reiniging en versoening (De Klerk, 1968:60). Hierdie vergeldingslyde is in Christus vernul sodat die lyde sy vergeldingskarakter verloor, maar sy tugtigende, opvoedende karakter behou (1 Kor. 11:32; Heb $12: 6,7,10)$.

De Klerk $(1968: 61,62)$ toon aan dat daar 'n verband kan bestaan tussen individuele tyde en skuld. Vir die gelowige is hierdie individuele lyde as gevolg van skuld dan kastyding tot behoud. Die waarheidsmoment hierin is dat die gelowige, wat naby aan God is, dikwels, en ook in sy nood, met die beskikkende hand van sy Hemelse Vader te doen het en daaroor moet besin: hy sal oor sy sondes nadink en hom berouvol oor spesifieke dade verootmoedig. Ook mag hy sy lyding moontlik beleef as 'n tugtiging vir 'n spesifieke sonde; ook dit sal waarskynlik tot 'n verdieping van sy geloof lei (vgl. onder andere Jak. 1:2,3). Daar lê egter ook 'n gevaar in hierdie siening asof 'n mens met sy menslike verstand wil indelf in die goddelike raad en regering, want God se weë bly ondeurgrondelik (Rom 11:33).

Hoewel daar in die Bybel voorbeelde is van bepaalde strawwe vir bepaalde sondes (vgl. Dawid se sonde met Batseba en die dood van die gebore seun), bly dit Goddelike openbaring. Daar kan nie vandag, met dieselfde sekerheid as in die geval van Dawid, 'n bepaalde situasie aan 'n bepaalde menslike daad verbind word nie.

Vir die gelowige het lyding wel die waarde dat dit opvoeding ten goede is. Voorbeelde hiervan (vgl. De Klerk, 1968:62) is die volgende: Jona 2: opvoeding tot afkeer van sonde en inkeer tot God; Job 36:15: opvoeding tot 'n oorgegewe en 
aandagtige luister na God; Romeine 5:3-5: opvoeding to Christelike deugde; 2 Korintiërs 12:7: opvoeding tot nederigheid en oorgawe aan God se wil, Hebreërs 12:10: opvoeding tot heiligmaking en groei in die geloof.

\subsection{Die bediening aan dic gelowiges}

\subsubsection{Die gebed}

Die bedienaar moet sy werk biddend doen. Bid die bedienaar werklik en doelgerig voor elke situasie? Bid hy ook voor die gesprek begin? Roep hy ook andere op om saam met hom vir die nood van spesifieke gelowiges te bid? Die bediening moet nie net 'n bediennng van die Woord wees nie, maar ook 'n bediening vall die gebede (Hand 6:4)

Die gebed is vir die gelowige ""n soeke en roepe na God" (Muller, 1981:28) waarin die gelowige sy nabyheid by God beleef; daarom is die gebed die fondament waarop die bediening rus.

\subsubsection{Veelvuldige aspekte}

Bolkestein (1964:52-68) behandel verskillende woorde wat in die Nuwe Testament gebruik word oin die pastorale sorg (sielsorg) te beskryf: onder andere as herder bedien, toesig hou, vennaan ell vertroos, versterk, toerus, teregwys, bestraf, opbou. Hierby kan nog ander begrippe gevoeg word wat deur Venter (1976:108 e.v) as "Woordbedieningsbegrippe" bestempel word: onder andere gesagvol beveel, leer, aankondig, verkondig, onderrig.

J. Adams beklemtoon die begrip voronjors ell stel dat die noutetiese beraad se voordeel bestaan in die element van konfrontasie met die oog daarop om persoonlikheids- en gedragsverandering te bewerkstellig. Moontlik word hier te sterk op die vermanende en konfrontasie-aspek gekonsentreer ondat Adams te probleem-georiënteerd werk (vgl. Louw, 1982:11)

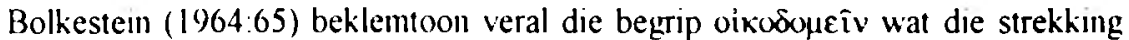
van alle sielsorg saamvat. Louw (1982:11 e.v.) onderstreep die belangrikheid van die begrip $\pi \alpha p \alpha \kappa \alpha \lambda \varepsilon \hat{i v}$ omdat dit die twee betekenisse vall vermaan en vertroos omvat (so ook Firet). Venter beskou hierdie begrip as "die samevattende NuweTestamentiese begrip vir die herderlıke bedienme" (1976:52).

Bogenoende begrippe onderstreep die veelkleurigheid van die bediening van die Woord aan gelowiges. Tog is dit raadsaam om nie een begrip uit te sonder en dit as 'n "generiese term" (Botha \& Janse van Rensburg, 1993:50) te yk me. Veral in die lig van die ontsaglike verskeidenheid situasies waann die wil van God gerealiseer word, behoor die bediennng van die belydenis oor die wil van God nie tot een term beperk te word nie 


\subsubsection{Die wesenlike van die bediening}

\subsubsection{Die bediening van die evangelie}

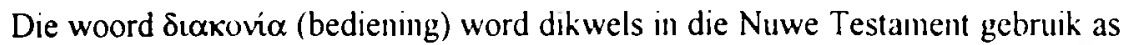
'n daad waardeur die gelowiges in hulle nood bygestaan word (Hand 6:1 e.v., 11: 29) en dui ook op die bediening van die Woord (Hand. 6:4).

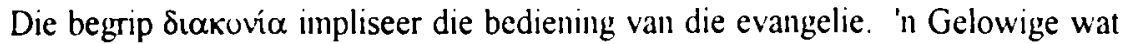
in nood is, byvoorbeeld finansiële nood, ervaar dit as koue, afsydige luulpverlening as diakonale hulp gebied word sonder on die imnige verhouding daar te stel: 'n innige verhouding met God en met die medegelowiges wat die lulp verskaf. Die gelowige in nood behoor derlalwe met trooswoorde uit die Heilige Skrif ondersteun te word. Hy moet die innigheid van die liefde van Christus in die hulp besef omdat dit hom daantoe lei om die wil van God in sy nood te kan raaksien en aanvaar.

Hierdie bediening moet die han van die lidmaat raak. Hy moet in 'n imnige verhouding met God kom sodat hy die appèl kan hoor: My seun, gee my jou hart, want God soek die hart van die mens (vgl. Rom. 10:8,9). Bediening wat nie dic hart van die mens raak nie, is koud en kan die mens in 'n koue, afstandsverhouding met God bring vanwaar hy moeilik die wil van God in sy lewe sal kan verwerk.

\subsubsection{Die werk van Jesus ( hristus}

Die bediening van die kerk is die bediening van die evangelie van Jesus Christus. Hy word verkondig as die Een in wie daar vergiffenis van sonde is, deur wie daar bevryding van en oorwinnmg oor sondes kom en van wie daar leiding en begeleiding in die toekoms uitgaan. Dit is dus 'n bediening van die versoening (vgl Venter, 1976:37 e.v.) in Jesus Christus waardcur die gelowige hoop kry en seker is van die innige liefde van God vir hom

Die perspektıef op die lyde van Jesus Christus is 'n belangrike element in die bediening van die Woord aan gelowiges wat self ly. Christus se lyding is middelaarslyding - dit kan nooit van die mens se lydnng gesê word nie Jesus se lyding gaan die mens s'in ver te bowe in intensiteit en betekenis; sy lyde is uniek en onherhaalbaar (Louw, 1982:24). Die gelowige in sy nood kan dus getroos word met die besef dat Christus vir hom gely het, maar die gelowige kan nooit werklik soos Christus ly nie. God verwag dit ook nie van die mens nie. Die woorde in Hebreërs 12:4: "Julle het nog nie ten bloede toe weerstand gebied in julle stryd teen die sonde nie" beteken nie dat God van die gelowige veruag on dit te doen nie (Moffat, 1924:199). Jesus het, as Leidsman en Voleinder van die geloof, klaar tot die dood toe, ten bloede toe, gely (Heb 12:2). 
Ook verwag God nie van die gelowige dat hy soos Christus moet ly on deur sy eie lyde die verhouding met God te herstel nie. Hierdie verhouding is reeds deur die lyding van Christus herste!

\subsubsection{Dic werk van die Iteilige Gees}

Jesus is die Middelaar, die Heilige Gees die Bemiddelaar (Louw, 1982:12). Die Heilige Gees stig en bou die verhouding tussen God en die gelowige. Hy is die belofte van die Vader (Hand 1.5) deur wie Jesus sy dade ell woorde voortsit (Venter, 1986:93) en sodoende die gelowiges se band met God opbou.

Die Heilige Gees word ook bedien as die Een wat as Trooster (Joh. 14:16) by die gelowiges bly en luulle die krag gee (Hand. 1:8). Met die Heilige Gees by en in die gelowige kan hy verlede, hede en tockoms in sy eie lewe integreer vanuit die posisie dat God naby aan hom is. Dan word die gelowige werklik getroos. Die Heilige Gees gee aan hom die hoop en visie op 'n eskatologiese toekoms waarin ly konkreet die convimming van Jesus Christus beleef in die besef dat God by lom is

\subsubsection{Die ontferminge van God}

In die bediening van die evangelie aan die lidmaal is die ontferminge van God (Rom. 12:1) 'n belangrike uitgangspunt. Die woord oiktipuoi is juis 'n woord wat dui op medelye, bamhartigheid, ontenming, "to show mercy and concen, with the implication of sensitivity and compassion" (Louw \& Nida, 1989). In die ontferminge van (jod beleef die gelowige sy minge verhouding met God.

Romeine 12:1 sluit by die voorafgaande deel van Romeine aan waar verskillende voorbeelde gegee is van hoe God hierdie barmhartigheid van Hom in die lewe van gelowiges betoon (vgl. Rom 8, 10:8-11; 11:32).

Die ontfenninge van God in Romeine 12:1 omsluit alles wat die gelowige glo van die genade van God vir hom Loun (1982:16-18) beklemtoon tereg die verbondsmatige karakier as een van die hoekstene vall die pastoraat (vgl. Muller, 1981:33-36), dit slut in die ()-Testamentiese beloftes ell verbondstrou van God en die wyse waarop God in Jesus Christus sy ontferminge oor die mens in nood uitgestort liet

\subsubsection{Bemoediging}

Die wil van God impliseer ook 'n positiewe bemoediging van die gelowige. Hy' hoef nie bedien te word net on die wil van God te aanvaar nie, maar ook on die wil van God tot sy eie bemoediging en troos in geloof aan te wend. 
Eerstens is dit tog die wil van God dat sy gelowige kinders gered en versorg word. God wil die goeie vir sy kinders.

Verder hou die wil van God in dat die gelowige se oog gevestig word op die eskatologiese hoop wat in Christus vir hom bestaan. Juis binne hierdie hoop skep die wil van God vir hom die ruimte waarbinne hy kan volhard.

Dit bring die gelowige derdens tot oorweging van die feit dat hy nie vra: Waarom ly ek nie, maar wel: Waartoe ly ek? Hoe kan ek deur my nood diensbaar wees aan God en my naaste?

Sodoende plaas die besef van die belangrikheid van die wil van God vir sy lewe die gelowige op 'n liniêre vlak. Hy word bevry uit die sirkelende maalkolk van sy worstelende vrae en word geplaas op die lyn van God se beskikking oor sy lewe.

\subsubsection{Die hand van God}

Die gelowige moet deur die evangelie bedien word dat hy (weer) tol die besef kom dat niemand hom uit die hand valı God kan ruk nie (Joh. 10:28, 29). In Johannes 10 word die veilige posisie van die skaap beskryf, dic gelowige wat veilig in God se hand is. Enersyds handel dit hier oor die ewige saligheid wat vas en seker is vir die gelowige, want Jesus sè self in Johannes 10:28 dat niemand uit sy hand geruk word nie. Andersyds gaan dit ook oor die beskennende hand van die Vader vir sy kinders wat in 'n bose wêre'il leef (Grosheide, 1950:132).

Die gelowige moet rus vind binne hierdie innige band tussen hom en sy Vader, sodat hy van hoinself en sy eie situasie kan sê: "Ek is in die hand van my Vader veilig op grond van sy liefde vir my ondat ek weet dat Jesus vir my die liefde van God verseker het. Hy vou my toe in sy hande. Niks glip uit sy hande uit nie.' Binne hierdie innige verhouding word die wil van God vir die gelowige in nood 'n genadige, liefdevolle en beskennende wil. Vir die gelowige is al wat hy dan begeer om naby God te wees (Ps. 73:28).

\subsubsection{Vermanende optrede}

Die gelowige moet tot 'n oorwinning oor die nood begelei word. Die bediening het in hierdie opsig 'n vermanende aspek. Op grond van die genade van God kan die gelowige opgeroep word tot geloofsverantwoordelikheid (Louw, 1982:16). Vanuit sy posisie om naby aan God te wees, is hierdie oproep tot oorwinning nie 'n koue bevel nie, maar 'in troosvolle bemoediging.

Volgens Filippense 2:13 (“... werk julle eie heil uit met vrees en bewing; want dit is God wat in julle werk on te wil en on te werk na sy welbelae ...") skakel God se wil nie die mens se wil uit nie. God se wil bepaal en rig juis die gelowige se wil on te besef "met my God spring ek oor 'n muur" (Ps. 18:30). Juis omdat die 
nood van die gelowige Hom tot die besef bring dat hy naby aan God is, kan hy op grond van hierdie sekerheid die nood oorwin.

\subsubsection{Bediening en kotvavía}

Die bediening se doel is om ook die gelowiges in hulle onderlinge band saam te bind. Omdat die gelowiges saain deel aan die evangelie met sy trinitariese inhoud, is hulle as deel vall die liggaan van Christus aan mekaar verbind ( 1 Kor. 12:12 e.v.). Daar bestaan 'n kutwwía, 'n onderlinge verbintenis aan mekaar, wat nie allecn 'n objektiewe feit van saam-wees beteken me, maar dit word ook 'n saam-leef (I Kor. 12:26).

Die bediening aan die gelowige in nood geskied vanuit 'n hegte verhouding tussen gelowiges onderling op grond van hulle gemeenskaplike imige band inet die Here Een van die hoofdoelstellings van die kerklike bedienng behoon te wees om hierdie innige band tussen gelowiges daar te stel. Die bestaan van hierdie band skep vir die gelowige die ruimte om in sy eie nood ook saam met mede-gelowiges die wil van God te verwerk. Maar "... sonder die verband met die gemeente is die komnunikasiegebeure van die paraklese 'n eensame steriliteit" (Louw, 1982:14).

\subsubsection{Bediening en huisgesin}

Dit is nie sonder rede dat Psalın 68:7 sê dat God eensames in 'n luuisgesm plaas me Die mens word dikwels bunne sy huisgesin betrek (Ef 5:22 - 6:9). Huisgesm korrespondeer met die begrip wommg. In die Bybel is woning dikwels die simbool van veiligheid en geborgenheid. In Psalm 84:2-5 word woning ook gebnuik as beeld van die imnige gemeenskap met God.

Verder is dit belangrik dat God Hom dikwels as die Vader van die gelowiges aandui. Volgens Hebreërs 12 kom die tugtiginge uit die hand van die hemelse Vader. Die hemelse Vader gaan alle aardse vaders se tugtiginge ver te bowe $(12: 5-10)$.

Die imnigheid van 'n verhouding word juis binne 'n husgesin geleer en aangeleer. Dit is daar waar liefde geleer word, waar geleer word om in 'n gesonde gesin die wil en besluite vall dic ouer te respekteer, daarom behoon in die kerklike bediening van die wil van God aan 'n gelowige die gesinslewe van die lidmate versterk te word In die beplanning van gemeente-opbouprogramme moet die opbou van 'n gesonde gesinslewe nie vergeet word nie ondat dit een van die belangrikste hoekstene is 
Die bediening van die wil van God aan geilowiges in moxd

\section{Afsluitend}

\subsection{Basiese uitgangspunte}

Twee basiese uitgangspunte het die ken van hierdie artikel gevonn:

\subsubsection{Geen verstandelike antwoorde nie}

Die vraag na die verhouding tussen die wil van God en die lyde van die gelowige word nie met verstandelike antwoorde opgelos nie.

Die nood van die inens moet veral sy hart in sy verhouding met God raak, en nie net sy verstand nie. Die bediening van die belydenis oor die wil van God in die gelowige se nood het nie 'n resep of 'n kits-antwoord nie Dit is eerder 'n proses waardeur die hart van die gelowige geraak word en hy begelei word op die pad van geloofsverinniging in al sy fasette.

\subsubsection{Geloofsverinniging}

Die begrip geloofsverimiging is wesenlik in die bediening van die evangelie rakende die wil van God en die situasie van die mens in nood. Die bediening moet geskied vanuit 'n driehoekige verhouding wat tot stand kom en in stand gehou moet word:

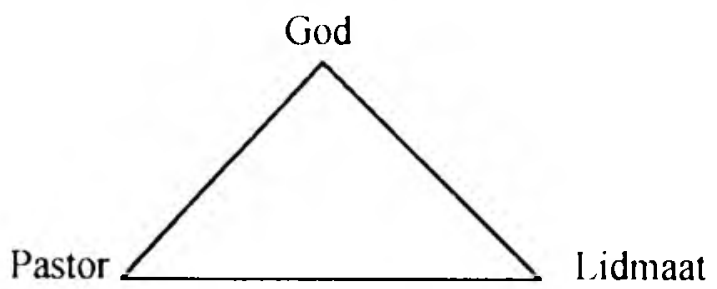

Eerstens moet die pastor in 'n innige verhoudng met God staan.

Tweedens behoort vanuit hierdie imnige verhouding ook ' $\mathrm{n}$ verinniging $\mathrm{m}$ die verhouding van die pastor/bedienaar tot die lidınat/gelowige te wees. In die bediening moet die pastor langs die gelowige en nie bo hom staan nie. Saan moet oor die wil van God in die nood van die mens besin en gebid word

Derdens moet die pastor vanuit hierdie twee innige verhoudinge die lidmaat bedien en begelei tot ' $n$ verimniging van die lidmaat se verhouding met God. Op hierdie wyse kan gekom word, nie noodwendig tot 'n begrip van die wil van God nie, maar wel tot 'n aanvaarding van die wil van God. On God se wil te aanvaar, 
is moontlik vanuit die besef dat God Hom met sy kind bemoei op grond van sy ontferminge deur Jesus Christus ell onder die leiding van die Heilige Gees.

\subsection{Praktiese konkretisering}

Enkele samevattende praktiese riglyne vir die bediening van die gelowige in nood word vervolgens gebied (vgl. Louw, 1982:26-40).

\subsubsection{Christologiese kommunikasie}

Vanuit die feit dat Jesus Chrisius as Verlosser bely word, moet die vertrekpunt in die kerklike bediening die geloof in Jesus as Saligmaker wees (vgl. Hand. 2:38; $3: 6 ; 4: 10,12,16: 31)$. Die sekerheid dat Jesus vir sy sonde gesterf het, gee aan die gelowige sekerheid van die liefde en nabylieid van die drie-enige God (1 Joh 5:13). Hierdie sekerheid is die basis vir die verinniging wat tussen God en die inens moet bestaan ten einde die wil en werke van God in 'n mens se lewe te kan aanvaar.

Die gelowige kan ook gebring word tot die besef dat hy ly soos Christus gely het, hoewel Jesus Christus se lyde uniek en onherhaalbaar is. In sy nood is die gelowige een met Christus in die sin dat Jesus vir hom gely het, die vloek van lyde verwyder het en as Hoëpriester langs hom in sy lyde koin staan.

\subsubsection{Vadergesentreerde integrasie}

Met die sekerheid in Jesus Christus as basis, moet die gelowige begelei word om God se wil as 'n mlatende wil (Louw, 1982:27) te siell. Dit beteken dat God die lyding en nood wil in soverte as wat $\mathrm{Hy}$ via die lyding met die mens se lewe bemoeienis maak. Tog impliseer God se wil nie maar 'n toelatende wil waar God eintlik passief die lyding van 'n afstand af toelaat nie: God se wil is 'n genadige wil wat verkondig: Ek wil die behoud van 'n sondaar

Die geloofsantwoord aan die gelowige in nood is dat God eintlik dit wil wat in die hart van die gelowige in nood gebeur. God wil dat die mens midde-in sy nood in sy ontfenninge sal bly glo en aan Hom alleen sal vashou (Rom. 12:1). Die gelowige moet begelei word on self in die Woord van God die ontferminge van God raak te sien en die beloftes van God duidelik te hoor.

In geloof moet die gelowige tot die besef gebring word dat die Vader erns met sy lyde maak en hom nooit in die lyde alleen laat nie. Hy bly in die hande van sy Hemelse Vader - daar waar hy die veiligste is 


\subsubsection{Pneumatologiese ondersteuning}

Die gelowige het die versekering dat die gemeenskap inet Christus ook gemeenskap met die Gees meebring en insluit (Fil 2:1). Die gelowige staan nie alleen in sy hantering en verwerking van die nood nie.

God wil die gelowige deur die Heilige Gees vertroos, ook deur hom die krag en volharding te gee om teen die nood te stry en daaroor te oorwin. God wil dat die gelowige bid vir die krag van die Gees ondat hy seker is dat die Heilige Gees hom in dinamiese beweging plaas om met hoop voort te gaan.

\subsubsection{Eskatologiese gerigtheid}

Ondat hy in 'n innige band met die drie-enige God verbind is, kan vir die gelowige die perspektief geopen word dat hy die sekerheid het dat hy wel nog deel is van hierdie skepping in barensnood (Rom 8:18, 22), maar dat die eskatologiese sekerheid vir hom verseker is. Die werkliklheid van sy eie geloof in die drie-enige God, die sekerheid van die getrouheid van God wat sy beloftes uitvoer en die vastigheid van die beloftes van 'n beter toekoms tot en met die ewige lewe, dra die gelowige in sy nood.

God wil dat die gelowige ook hierdie perspektief behou en nie net op die sigbare dinge let nie, maar ook op die onsigbare (2 Kor 4:16-18). God wil dat die gelowige die sekerheid van die oorwinning in Christus sal hê in die vaste hoop op dit wat met die wederkoms van Christus volkome sal realiseer

\subsubsection{Bestaansuitsig}

Omdat en in soverre die gelowige die imnige verhouding tussen hom en God besef, kan hy die vreugde in die geloof ervaar (Jak. 1:2). Hy kan bely dat hy ten spyte van alles, nogtans in die Here roem (Hab. 3:17). Hy kom tot die besef dat dit die Vader se wil was om hom al nader na Hom toe te bring en hom in sy geloof te verdiep (Heb. 12:11).

Hierdie uitsig is die eindpunt van die pastorale bediening aan iemand in nood. Dit kan nouliks van iemand in die diepte van sy nood verwag word om hierdie geloofsvreugde van die begin af te ondervind

Die einddoel van die gelowige se lewe is om God te verheerlik God se wil beteken uiteindelik dat die gelowige deur sy lyding heen gelei sal word om met oortuiging te bely: Uit God, en deur God en tot God is alle dinge. Aan Hom behoort die heerlikheid tot in ewigheid (Rom. 11:36).

\section{Bronnelys}

BOLKESTEIN, M H 1964 Zielszorg in het Nieuwe Testament Den Haag Van Keulen 
BOTHA, J \& JANSE VAN RENSBURG, F 1993 Paraenese of paraklese as generiese terme vir Nuwe-Testamentiese moral exhortation. In die Skriflig, 27(1):29-51, Maart

DE KLERK, W J 1968 Rousmart Die pastorale sorg oor bedroefdes na die oorlye van 'n dierbare Johannesburg: Evangelis

GREIJDANUS, S 1941. Het heilig evangelie naar de beschrijving van Lucas Amsterdam Bottenburg

GROSHEIDE, FW. 1950. Het heilig evangelie volgens Johannes Amsterdam Bottenburg

KITTEL, G., e'd 1969. Theological Dictionary of the New Testament Vol. 1 Grand Rapids : Eerdmans

KROEZE, JH 1961. Het boek Job. Kampen Kok

LOUW, D J 1982. Pastoraat en lyding Kaapstad NG Kerkbockhandel.

LOUW, J P \& NIDA, E A 1989 Greek-English Lexicon of the New Testament Based on Semantic Domains Cape Town Bible Society of South Africa

MOFFAT, J 1924 Epistle to the Hebrews Edinburgh : Clark

MULLER, B A 1981 Skrifgebruik in die pastoraat Kaapstad : NG Kerkboekhandel

PLUMMER, A 1942 Gospel According to St Luke Edinburgh Clark

RIDDERBOS, H 1959 Aan de Romeinen Kampen Kok

SWANEPOEL, F A 1992 Hoe kan/may ons oor God praat? (/n Swanepoel, F A, red., God en lyding Perspektiewe uit die boek Job Pretoria Powell p 43-52)

VENTER, A GS 1986 Die uerk van die Heilige Gees in die opbou van die kerk volgens Handelinge Potchefstroom PU vir CHO (Th D-proefskrif)

VENTER, C JH 1976 Die bediening van die versoening aan die bejaarde 'n Pastorale studie in die lig van die Pastorale Briewe Potchefstroom Pro Rege

WESSELS, J 1991 Coping with a Crisis Pretoria Powell 
